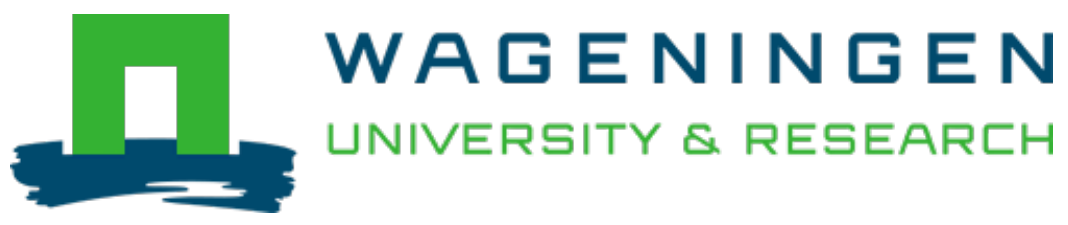

\title{
Microbiota of cocoa powder with particular reference to aerobic thermoresistant spore-formers
}

\author{
Food Microbiology \\ Líma, L.J.R.; Kamphuis, H.J.; Nout, M.J.R.; Zwietering, M.H. \\ https://doi.org/10.1016/j.fm.2010.11.011
}

This publication is made publicly available in the institutional repository of Wageningen University and Research, under the terms of article $25 \mathrm{fa}$ of the Dutch Copyright Act, also known as the Amendment Taverne. This has been done with explicit consent by the author.

Article 25 fa states that the author of a short scientific work funded either wholly or partially by Dutch public funds is entitled to make that work publicly available for no consideration following a reasonable period of time after the work was first published, provided that clear reference is made to the source of the first publication of the work.

This publication is distributed under The Association of Universities in the Netherlands (VSNU) 'Article $25 \mathrm{fa}$ implementation' project. In this project research outputs of researchers employed by Dutch Universities that comply with the legal requirements of Article $25 \mathrm{fa}$ of the Dutch Copyright Act are distributed online and free of cost or other barriers in institutional repositories. Research outputs are distributed six months after their first online publication in the original published version and with proper attribution to the source of the original publication.

You are permitted to download and use the publication for personal purposes. All rights remain with the author(s) and / or copyright owner(s) of this work. Any use of the publication or parts of it other than authorised under article $25 \mathrm{fa}$ of the Dutch Copyright act is prohibited. Wageningen University \& Research and the author(s) of this publication shall not be held responsible or liable for any damages resulting from your (re)use of this publication.

For questions regarding the public availability of this publication please contact openscience.library@wur.nl 


\title{
Microbiota of cocoa powder with particular reference to aerobic thermoresistant spore-formers
}

\author{
Lídia J.R. Lima ${ }^{\mathrm{a}}$, Henri J. Kamphuis ${ }^{\mathrm{b}}$, M.J. Rob Nout ${ }^{\mathrm{a}, *}$, Marcel H. Zwietering ${ }^{\mathrm{a}}$ \\ ${ }^{a}$ Laboratory of Food Microbiology, Wageningen University, P.O. box 8129, 6700 EV Wageningen, The Netherlands \\ ${ }^{\mathrm{b}}$ Cargill Cocoa \& Chocolate, P.O. Box 82, 1530 AB Wormer, The Netherlands
}

\section{A R T I C L E I N F O}

\section{Article history:}

Received 17 September 2010

Received in revised form

17 November 2010

Accepted 18 November 2010

Available online 24 November 2010

\section{Keywords:}

Cocoa

Bacillus subtilis

Salmonella

Spore heat-resistance

Thermotolerance

16S rDNA phylogeny

Amplified fragment length polymorphism

\begin{abstract}
A B S T R A C T
The microbiological criteria of commercial cocoa powder are defined in guidelines instituted by the cocoa industry. Twenty-five commercial samples were collected with the aim of assessing the compliance with the microbiological quality guidelines and investigating the occurrence and properties of aerobic Thermoresistant Spores (ThrS). Seventeen samples complied with the guidelines, but one was positive for Salmonella, five for Enterobacteriaceae and two had mould levels just exceeding the maximum admissible level. The treatment of the cocoa powder suspensions from $100{ }^{\circ} \mathrm{C}$ to $170{ }^{\circ} \mathrm{C}$ for $10 \mathrm{~min}$, revealed the presence of ThrS in 36\% of the samples. In total $61 \mathrm{ThrS}$ strains were isolated, of which the majority belonged to the Bacillus subtilis complex (65.6\%).

Strains resporulation and spore crops inactivation at $110{ }^{\circ} \mathrm{C}$ for $5 \mathrm{~min}$ showed a wide diversity of heatresistance capacities. Amplified fragment length polymorphism analysis revealed not only a large intraspecies diversity, but also different clusters of heat-resistant spore-forming strains. The heatresistance of spores of six $B$. subtilis complex strains was further examined by determination of their $D$ and $z$-values.

We concluded that $B$. subtilis complex spores, in particular those from strain M112, were the most heat-resistant and these may survive subsequent preservation treatments, being potentially problematic in food products, such as chocolate milk.
\end{abstract}

(c) 2010 Elsevier Ltd. All rights reserved.

\section{Introduction}

The processing chain of cocoa beans (Theobroma cacao L. fruit seeds) for cocoa powder production starts in tropical countries, where farmers, after harvesting the cocoa pods, submit the beans to a process of natural fermentation, the "sine qua non" for the distinctive cocoa flavour development ensued by roasting (Lima et al., in press; Schwan and Wheals, 2004). Following the fermentation, the cocoa beans are dried and shipped to industrial plants, where intermediate or final products are manufactured. For the production of cocoa powder, cocoa beans from different origins are blended, roasted and processed into a mass, which is subsequently partially defatted to minimum levels of $20 \%$ or between 10 and $20 \%$ (dry weight matter) and pulverised (Anon., 1981; Kamphuis, 2009). Prior to roasting, alkalisation of cocoa beans is generally applied to improve organoleptic and technological attributes of cocoa powder (Kamphuis, 2009).

\footnotetext{
* Corresponding author. Tel.: +31 31748 2834; fax: +31 317484978 . E-mail address: rob.nout@wur.nl (M.J.R. Nout).
}

Whereas diverse microorganisms are present at high numbers during cocoa beans fermentation, subsequent post-harvest and industrial processing operations allow only the survival of a microbiota dominated by the genus Bacillus and relatives (Barrile et al., 1971). The ability of members of this group to form endospores, in some cases of extreme heat-resistance, implies that they may survive industrial processes and pose spoilage and safety problems (Huemer et al., 1998; Oh and Cox, 2009; Oomes et al., 2007).

The general microbiological composition of commercial cocoa powder was investigated previously, revealing total aerobic microbial levels between 2 and $4.4 \mathrm{log} \mathrm{cfu} / \mathrm{g}$, with Bacillus licheniformis, Bacillus cereus, Bacillus megaterium and Bacillus subtilis constituting, respectively, 45, 20, 10 and $8 \%$ of the isolates (Gabis et al., 1970). In another study, in addition to total aerobic microorganisms, spores populations surviving heat-treatments of $80^{\circ} \mathrm{C}$ and $100^{\circ} \mathrm{C}$ during 1 and 5 min were analysed, and this showed $B$. subtilis and $B$. licheniformis to represent $83 \%$ of the isolates (Mossel et al., 1974).

Although the aforementioned reports are of interest in comparative studies of cocoa microbiota, they offer less insight into the occurrence and properties of highly heat-resistant spores in cocoa 
powder. These are a problem for further preservation of cocoa products, namely in Ultra High Temperature (UHT) treatment of chocolate-flavoured milk. To our knowledge, no published data are available about the occurrence, identity and thermal kinetic parameters of highly heat-resistant spores in cocoa powder. Furthermore, in view of the detection and control of these spores within the food industry, it is important to understand whether a highly heat-resistant spore phenotype is associated with a specific genotype, or if it can be found in isolates bearing considerable genotypic dissimilarity.

Presently, the only reference pertaining to the microbiological quality of commercial cocoa powder consists of guidelines defined by cocoa industrials (Dijk et al., 2007). These guidelines, which are the only reference the industry relies on, include specifications for total aerobic mesophiles ( $<5000 \mathrm{cfu} / \mathrm{g}$ ), moulds ( $<50 \mathrm{cfu} / \mathrm{g}$ ), yeasts $(<10 \mathrm{cfu} / \mathrm{g})$, Enterobacteriaceae (absent in $1 \mathrm{~g}$ ) and Salmonella (absent in $25 \mathrm{~g}$ ).

This work reports the assessment of compliance of commercial cocoa powder samples with the microbiological quality guidelines and the investigation on the occurrence, levels and properties of aerobic Thermoresistant Spores in those samples. We defined 'Thermoresistant Spores', as spores able to survive a heat-treatment of at least $100{ }^{\circ} \mathrm{C}$ for $10 \mathrm{~min}$. This enabled the isolation and identification of predominant Thermoresistant Spore-formers, characterisation of the diversity of heat-resistant properties of their spores produced under standardised conditions and appraisal of strains genotypic variability.

\section{Materials and methods}

\subsection{Cocoa powder samples}

Twenty-five cocoa powder samples (packages or tins of $125-500 \mathrm{~g}$ ) were purchased in retail shops (21 different brands) or obtained from an industrial processor (4 samples). In total, 13 samples were from Europe, 3 from South America, 3 from Africa, and 6 from Asia (11 countries in total). They consisted of $100 \%$ cocoa powder, with fat contents between $10-12 \%$ and $20-22 \%$ (w/w) (in half of the cases, this information was not provided). One of these samples was sold in a solidified form, with an unspecified fat content ('cocoa-cookie'). No information was given in the packages with respect to the processing applied or the origin of the cocoa beans. All the samples were stored at room temperature and analysed before the expiration date.

\subsection{Microbial groups enumeration and detection}

The content of each cocoa powder package was aseptically transferred and mixed in a sterile polyethylene sampling bag. Ten grams of each sample were collected into a stomacher bag with filter and homogenised with $90 \mathrm{ml}$ of Peptone Physiological Saline solution (PPS) (1 g Neutralized Bacteriological Peptone [NBP, Oxoid] and $8.5 \mathrm{~g} \mathrm{NaCl}$ per liter) for $1 \mathrm{~min}$, in a Stomacher lab-blender 400 (Seward Medical) by selecting the 'normal' speed setting. The preparation of the 'cocoa-cookie' was performed as described in Dijk et al. (2007) for cocoa mass. Subsequently, after serial tenfold dilutions in PPS, $1 \mathrm{ml}$ of the appropriate dilution was pipetted into duplicate plates and the appropriate medium was distributed according to the pour-plating technique. An aliquot of the primary dilution was also used to measure the pH (WTW 525, electrode Sentix 4.1). Total Aerobic Microorganisms (TAM) were enumerated in Plate Count Agar (PCA, Oxoid), after incubation at $30{ }^{\circ} \mathrm{C}$ (mesophiles) for $72 \mathrm{~h}$ and $55{ }^{\circ} \mathrm{C}$ (thermophiles) for $48 \mathrm{~h}$. Yeasts and moulds were enumerated in pour-plates of Oxytetracycline Glucose Yeast Extract Agar (OGYE, Oxoid) after incubation at $25^{\circ} \mathrm{C}$ for 5 days. Enterobacteriaceae detection was performed according to the method described in Dijk et al. (2007) with incubations at $37{ }^{\circ} \mathrm{C}$. Pre-enrichment of $1 \mathrm{~g}$ of cocoa powder was performed overnight (18h) in Buffered Peptone Water (BPW, Oxoid), followed by enrichment in Enterobacteriaceae Enrichment broth (EEB, Oxoid). Next, the incubated EEB was subcultured on a pre-poured plate of Violet Red Bile Glucose Agar (VRBGA, Oxoid) under microaerophilic conditions. Representative characteristic colonies were confirmed by the oxidase and glucose fermentation tests. Salmonella was detected in $25 \mathrm{~g}$ of cocoa powder as described in Dijk et al. (2007), with the exception that the BPW was supplemented with Skim Milk Powder (SMP, Oxoid) $100 \mathrm{~g} / \mathrm{l}$. After overnight incubation for $18 \mathrm{~h}$ at $37^{\circ} \mathrm{C}$, a secondary enrichment in Rappaport-Vassiliadis Soya broth (RVS, Oxoid) and Modified Semi-solid Rappaport-Vassiliadis Soya medium (MSRV, Oxoid) was performed at $41.5{ }^{\circ} \mathrm{C}$ for $24 \mathrm{~h}$. Next, selective culturing was done at $37{ }^{\circ} \mathrm{C}$ for $24 \mathrm{~h}$ on Brilliant Green Agar (BGA, Oxoid) and Xylose Lysine Desoxycholate Agar (XLD, Oxoid) from both previously incubated media. Presumptive Salmonella colonies were characterised by biochemical, serological and serotyping tests at the National Institute for Public Health and the Environment of The Netherlands (RIVM, Bilthoven). All media were prepared according to the manufacturers' instructions.

\subsection{Total and thermoresistant spores enumeration and strains isolation}

For aerobic Total Spores (TS) determination, $10 \mathrm{ml}$ of the primary dilution were pasteurised at $80^{\circ} \mathrm{C}-10 \mathrm{~min}$ prior to pour-plating with PCA (TS were enumerated based on the same primary dilution as for general microbial groups in 2.2). Plates incubation conditions were as for described for TAM. The heat-treatments were done in screw-capped $120 \times 15 \mathrm{~mm}$ stainless steel (type 304 ) tubes. The caps had a central hole of $8 \mathrm{~mm}$, through which a removable silicone membrane of $3 \mathrm{~mm}$ thickness was visible. Heating was performed by immersing the tubes in a circulating bath filled with glycerol (Fluka 49780), at the desired temperature, followed by cooling with vigorous shaking in icy water at the end of the set time (at $80{ }^{\circ} \mathrm{C}$ the come-up time was $120 \mathrm{~s}$, while cooling to room temperature took $15 \mathrm{~s}$ [Squirell data logger, Eltek]).

For aerobic Thermoresistant Spores (ThrS) enumeration, fresh cocoa powder dilutions were made, after which heat-treatments of $100^{\circ} \mathrm{C}-10 \mathrm{~min}, 100^{\circ} \mathrm{C}-30 \mathrm{~min}, 108^{\circ} \mathrm{C}-30 \mathrm{~min}, 110^{\circ} \mathrm{C}-10 \mathrm{~min}, 120^{\circ} \mathrm{C}-$ $10 \mathrm{~min}, 150^{\circ} \mathrm{C}-10 \mathrm{~min}$ and $170^{\circ} \mathrm{C}-10 \mathrm{~min}$ were applied. This was followed by pour-plating with PCA and plates incubation at $30{ }^{\circ} \mathrm{C}$ for 5 days and at $55^{\circ} \mathrm{C}$ for 3 days. In addition, for ThrS enumeration, $1 \mathrm{ml}$ of heated cocoa powder suspension was serial-diluted in Tryptone Soya Broth (TSB, Oxoid) supplemented with SMP $100 \mathrm{~g} / \mathrm{l}$ (Park et al., 1979), according to the three-tube Most Probable Number (MPN) technique (Blodgett, 2006). Tubes incubation was also at $30^{\circ} \mathrm{C}$ for 5 days and at $55^{\circ} \mathrm{C}$ for 3 days. Samples plating took place in a flow cabinet, with incorporation of negative control plates and tubes. After incubation, the result of each tube was confirmed by streaking $10 \mu \mathrm{L}$ on a PCA plate. The MPN index and the confidence intervals were calculated using the Food and Drug Administration MPN Excel spreadsheet available online (Blodgett, 2006). Colonies were randomly selected from the lowest dilution of ThrS plates or plates from the MPN technique (when the level of ThrS counting plates was below the detection limit). They were purified by dilution streaks on Nutrient Agar (NA, Oxoid) and after growth, the macro and micromorphology were inspected for purity confirmation. Stock cultures were kept in Nutrient Broth (NB, Oxoid) with glycerol $25 \%(\mathrm{v} / \mathrm{v})$ (Fluka, 49782 ) and stored at $-80^{\circ} \mathrm{C}$.

With exception of Enterobacteriaceae, Salmonella and ThrS, all the determinations were performed in duplicate independent experiments. 


\subsection{Thermoresistant spore-formers identification}

\subsubsection{Phenotypic characterisation}

The isolates were first confirmed to the genus level by colony and cell morphology, catalase production and Gram reaction (Gregersen, 1978). Endospore formation was monitored by phase contrast microscopy, after inoculation on the sporulation medium supplemented with different minerals that is described by Cazemier et al. (2001).

Strains coding was according to their isolation temperature: $\mathrm{M}$ (Mesophilic) for strains isolated at $30{ }^{\circ} \mathrm{C}$ and TT (Thermotolerant) for strains isolated at $55^{\circ} \mathrm{C}$.

The ability of the strains to ferment and assimilate carbon sources was determined using API 50 CHB system (BioMérieux,France) according to the manufacturer's instructions. The results were analysed with the APIWEB tool v4.0 (https://apiweb.biomerieux.com/ servlet). The type strains Geobacillus stearothermophilus DSM5934 and $B$. subtilis DSM10 were included in the API test as comparison. They were obtained from the Deutsche Sammlung von Mikroorganismen und Zellkulturen (DSMZ, Germany).

Strains motility was determined by stab inoculation of tubes with motility medium (Casein Digest [CD, Difco] $20 \mathrm{~g} / \mathrm{l}$, Meat Peptone [MP, Oxoid] $6.1 \mathrm{~g} / \mathrm{l}$ and Agar Bacteriological [AB, Oxoid] $3.5 \mathrm{~g} / \mathrm{l}$ ), followed by incubation at $30^{\circ} \mathrm{C}$ for 2 days. B. cereus ATCC 14579 (Laboratory of Food Microbiology, Wageningen University) was used as a positive control.

\subsubsection{Genotypic characterisation}

DNA was isolated from cultures grown overnight using the Wizard genomic DNA purification kit (Promega Corporation), following the manufacturer's instructions. The DNA extracts were directly used to amplify the 16S rRNA gene using universal primers (Edwards et al., 1989). Amplifications were performed in the thermocycler GeneAmp PCR System 9700 (Applied Biosystems), with an annealing temperature of $56{ }^{\circ} \mathrm{C}$ and using chemicals and Taq DNA polymerase from Fermentas. The PCR products were sequenced with the same set of primers by GATC Biotech (Germany). The resulting sequences were assembled in SeqMan (Lasergene v5.08, Dnastar Inc.). The contigs were compared to similar sequences (Altschul et al., 1990) in the GenBank database at the National Center for Biotechnology Information (NCBI) (http:// blast.ncbi.nlm.nih.gov/). The isolates were assumed to belong to a given species if the similarity between the query 16S rDNA sequence and the sequences in the databases was higher than $97 \%$ (Stackebrandt and Goebel, 1994). The nucleotide sequences have been deposited in GenBank under the accession numbers GQ340461-GQ340521. The tree builder tool provided by the Ribosomal Database Project (RDP) was then used to create a phylogenetic tree. The sequences of the type strains of B. subtilis (DSM10) and Clostridium sporogenes (DSM795) were retrieved from the RDP and included in the alignment.

Strains genetic diversity was analysed using the Amplified Fragment Length Polymorphism (AFLP) method (Vos et al., 1995), with the AFLP Analysis System Kit for Microorganisms (Invitrogen). This technique was performed according to Myburg et al. (2001), with fragment separation and detection on a Li-COR automated sequencer. After preliminary screening of candidate primers and analysis of reproducibility (the same profile was sucessfully generated in duplicate independent experiments for 8 strains), two primer combinations EcoRI-A/MseI-C and EcoRI-C/MseI-G were selected for DNA digestion (60-70 ng) and generation of strains fingerprints. Digital AFLP gel images were scored for the presence and absence of bands in the range 50-550 bp, using AFLPQuantar (v1.05, KeyGene). Both monomorphic and non-monomorphic bands were scored. Bands with the same mobility were scored as identical.
The 2 binary data sets were subsequently combined and imported into Treecon v1.3b (Van de Peer and De Wachter, 1994), where a phylognetic tree was inferred using Nei and $\mathrm{Li}$, and Neighbour joining methods.

\subsection{Preparation of spore crops of thermoresistant strains and heat- inactivation assay}

Isolates sporulation was achieved as described in section 2.4.1. For the preparation of overnight cultures, $25 \mathrm{ml}$ of NB in an Erlenmeyer of $100 \mathrm{ml}$ were inoculated with a loopful of cell culture from the glycerol stock and incubated at $200 \mathrm{rpm}$ at $37^{\circ} \mathrm{C}, 45^{\circ} \mathrm{C}, 50^{\circ} \mathrm{C}$ or $55^{\circ} \mathrm{C}$ for $16 \mathrm{~h}$ in a water bath. One milliliter of the overnight culture was spread onto plates containing the sporulation media. These were incubated at the same temperature as growth occurred, until more than $95 \%$ of the spores had been released from the sporangium (2-4 days). Spores were harvested with $10 \mathrm{~mL}$ of Phosphate Buffer (PB) $10 \mathrm{mM} \mathrm{pH} 7.0$ (tenfold dilution of $0.1 \mathrm{M} \mathrm{K}_{2} \mathrm{HPO}_{4} / \mathrm{KH}_{2} \mathrm{PO}_{4}$ buffer). Tween $801 \mathrm{ml} / \mathrm{l}$ (Merck) was added to $\mathrm{PB}$ for isolates of $B$. cereus complex. The spores were purified by 4 successive centrifugational washings with $\mathrm{PB}$ at $4{ }^{\circ} \mathrm{C}$, during 5 days, at $1157 \mathrm{~g}$ for $7 \mathrm{~min}$ and at $4629 \mathrm{~g}$ for $5 \mathrm{~min}$, in an Eppendorf centrifuge (5804 RF, Rf-34-6-38) cooled at $4{ }^{\circ} \mathrm{C}$. For strains M27, TT45 and B. subtilis DSM10, gradient centrifugations in Nycodenz (Axi-Shield PoC) were used to separate the spores from the vegetative cells and debris. Briefly, $500 \mu \mathrm{l}$ of concentrated spore suspension were resuspended in Nycodenz $20 \%$ $(\mathrm{w} / \mathrm{v})$ and gently pipetted on the top of a 1:1, 30: 60\% gradient, in a $15 \mathrm{ml}$ conical tube (Greiner bio-one). The tubes were centrifuged at $4100 \mathrm{~g}$ in a centrifuge Firlabo SW $12 \mathrm{R}$, set at $20{ }^{\circ} \mathrm{C}$ for $45 \mathrm{~min}$. Following this step, the spores were washed six times with demineralised water and resuspended in PB. Working spore crops concentration were adjusted to levels between 7 and $8.5 \log \mathrm{cfu} / \mathrm{ml}$ and these were stored at $4{ }^{\circ} \mathrm{C}$.

A comparative study of spores wet heat-resistance was performed at $110^{\circ} \mathrm{C}$ for $5 \mathrm{~min}$ as described by Oomes et al. (2007), using the tubes and glycerol bath specified in the section 2.3. Next, appropriate tenfold dilutions of the tubes were cultivated in duplicate pour-plates of NB $2.6 \mathrm{~g} / \mathrm{l}$ solidified with AB $15 \mathrm{~g} / \mathrm{l}$. Plates incubation occurred at $37^{\circ} \mathrm{C}$ and $45^{\circ} \mathrm{C}$ for 5 days and $50^{\circ} \mathrm{C}$ for 3 days. The confirmation of the initial number of spores in the working spore suspension was achieved through injection of an unheated tube, followed by sampling as described above. For 6 strains, thermal inactivation parameters were additionaly determined. For this purpose, fresh spore crops were prepared and heated at different ranges: M65 $\left(95-105^{\circ} \mathrm{C}\right)$; M95 $\left(100-107.5^{\circ} \mathrm{C}\right)$; M35 $\left(100-115^{\circ} \mathrm{C}\right)$; M22 $\left(110-120^{\circ} \mathrm{C}\right)$; M1 $\left(110-122.5^{\circ} \mathrm{C}\right)$; and $\mathrm{M} 112\left(117.5^{\circ} \mathrm{C}-130^{\circ} \mathrm{C}\right)$. Survivors determination was done in duplicate plates.

\subsection{Thermoresistant spores survival data analysis}

The survival curves were fitted with the log-linear (equation (1)) and the Weibull models (equation (2)) (Mafart et al., 2002), according to the equations below:

$$
\begin{aligned}
& \log N(t)=\log N(0)-\frac{t}{D} \\
& \log N(t)=\log N(0)-\left(\frac{t}{\delta}\right)^{n}
\end{aligned}
$$

Where $D$ is the decimal reduction time, $\delta$ is the first decimal reduction time and $n$ is a shape parameter. Both models were fitted to the inactivation data in Microsoft Excel. For the Weibull model, parameters estimation was done with Excel Solver add-in and these were verified in TableCurve2D v.2.03 (Jandel Scientific), from which 
the confidence intervals for $n$ were also obtained. The log-linear model was fitted to all the data points, but when $\log N(t)$ was higher than $\log N(0)$ (strain M112) an additional fitting without $N(0)$ was also included. The number of data points in the survival curves was between 5 and 9 (except for M22 at $120^{\circ} \mathrm{C}$ and M112 at $130{ }^{\circ} \mathrm{C}$, where only 4 data points were available for the determinations, due to a fast inactivation). The goodness of fit of the models was determined by the mean square error of the model index (MSE $\mathrm{model}_{\text {le }}$ ) and analysis of the $95 \%$ confidence interval for the $n$-value. The temperature dependence of $D$ and $\delta$ was expressed in the $z$-value concept. This value was calculated by the negative reciprocal of the slope of the plot $\log D$ (or $\log \delta$ ) against the temperature. To obtain reliable estimates for the $z$-value, $D$ or $\delta$ values 2.5 times higher than the measured experimental duration (12 $\mathrm{min}$ ) were excluded.

\section{Results}

\subsection{Cocoa powder compliance with the microbiological quality guidelines}

The microbiological composition of the analysed commercial cocoa powder samples is presented in Table 1 . Whereas yeasts were below the detection limit of $1 \log \mathrm{cfu} / \mathrm{g}$, other microbial groups were present at diverse levels. In total, eight out of the twenty-five samples did not comply with the microbiological quality guidelines: samples P10 and P20 had mould levels that just exceeded the maximum admissible levels; samples P1 to P4 and P8 were positive for Enterobacteriaceae; and sample P12 was positive for Salmonella (serotype nigeria).

\subsection{Occurrence and levels of total and thermoresistant spores}

Apart from the Total Aerobic Microorganisms (TAM), also aerobic Total Spores (TS) were investigated. The level of mesophilic TS varied between $3.7 \log \mathrm{cfu} / \mathrm{g}$, in sample P12 and levels below the detection limit, in samples P21 and P23 (Table 1). On the other hand, thermophilic TS varied between $3.1 \mathrm{log} \mathrm{cfu} / \mathrm{g}$ in sample P12 and levels below the detection limit for 12 out of the 25 samples.

Table 2 summarises the estimated average levels and the Most Probable Number (MPN) for mesophilic and thermophilic aerobic Thermoresistant spores (ThrS). Mesophilic ThrS were detected in nine out of the twenty-five samples, while thermophilic ThrS were detected in three. Plate count and MPN techniques showed a good correspondence, as the log numbers were within the $95 \%$ confidence interval of the MPN technique. For mesophilic ThrS, we found survivors until a heat-treatment of $150^{\circ} \mathrm{C}-10 \mathrm{~min}$ (sample P2), whereas for thermophilic ThrS, survivors were found up to $110^{\circ} \mathrm{C}-10$ min (sample P12). In total 61 thermoresistant sporeforming strains were isolated for further study, 48 of which isolated at $30^{\circ} \mathrm{C}$ and 13 at $55^{\circ} \mathrm{C}$.

\subsection{Thermoresistant spore-formers identification and molecular typing}

All isolates were found to be Gram and catalase positive rods. Phase bright endospores were observed, with exception for strains M13 and TT50. For these strains, even with prolonged sporulation up to 15 days, increased $\mathrm{MnSO}_{4}$ concentration from 3 to $6 \mathrm{~g} / \mathrm{l}$ and incubation in the range $20^{\circ} \mathrm{C}-45^{\circ} \mathrm{C}$ for $\mathrm{M} 13$, and $45^{\circ} \mathrm{C}-70{ }^{\circ} \mathrm{C}$ for

Table 1

Estimated average levels $(\log \mathrm{cfu} / \mathrm{g})^{\mathrm{a}}$ and occurrence of general microbiological groups in commercial cocoa powder samples.

\begin{tabular}{|c|c|c|c|c|c|c|c|c|c|}
\hline $\begin{array}{l}\text { Sample code/ } \\
\text { Origin }^{\mathrm{b}} / \mathrm{Fat}^{\mathrm{c}}\end{array}$ & $\mathrm{pH}$ & $\begin{array}{l}\text { Total aerobic } \\
\text { mesophiles }\end{array}$ & $\begin{array}{l}\text { Total aerobic } \\
\text { thermophiles }\end{array}$ & $\begin{array}{l}\text { Aerobic total } \\
\text { mesophilic spores }\end{array}$ & $\begin{array}{l}\text { Aerobic total } \\
\text { thermophilic spores }\end{array}$ & Yeasts & Moulds & $\begin{array}{l}\text { Enterobacteriaceae } \\
\text { in } 1 \mathrm{~g}^{\mathrm{d}}\end{array}$ & $\begin{array}{l}\text { Salmonella } \\
\text { in } 25 \mathrm{~g}^{\mathrm{d}}\end{array}$ \\
\hline P1/E/L & 5.7 & $2.5(0.01)$ & $<1$ & $2.0(0.09)$ & $<1$ & $<1$ & $<1$ & + & - \\
\hline P2/E/L & 6.9 & $2.0(0.04)$ & $<1$ & $2.6(0.36)$ & $<1$ & $<1$ & $<1$ & + & - \\
\hline P3/E/L & 6.9 & $1.2(0.21)$ & $<1$ & $2.1(0.11)$ & $<1$ & $<1$ & $<1$ & + & - \\
\hline P4/E/ns & 6.7 & $1.9(0.16)$ & $<1$ & $1.8(0.32)$ & $<1$ & $<1$ & $<1$ & + & - \\
\hline P5/E/ns & 7.0 & $1.2(0.09)$ & $<1$ & $0.4(0.49)$ & $<1$ & $<1$ & $<1$ & - & - \\
\hline P6/E/ns & 7.2 & $2.1(0.14)$ & $<1$ & $2.2(0.01)$ & $<1$ & $<1$ & $<1$ & - & - \\
\hline $\mathrm{P} 7 / \mathrm{E} / \mathrm{ns}$ & 7.0 & $0.5(0.71)$ & $<1$ & $0.9(0.34)$ & $<1$ & $<1$ & $<1$ & - & - \\
\hline P8/E/ns & 6.8 & $1.3(0.00)$ & $<1$ & $1.0(0.00)$ & $<1$ & $<1$ & $<1$ & + & - \\
\hline $\mathrm{P9} / \mathrm{E} / \mathrm{ns}$ & 7.1 & $2.2(0.00)$ & $<1$ & $2.2(0.12)$ & $0.4(0.49)$ & $<1$ & $<1$ & - & - \\
\hline P10/E/H & 7.5 & $3.0(0.15)$ & $1.5(0.28)$ & $2.5(0.06)$ & $1.0(0.43)$ & $<1$ & $1.8(0.59)$ & - & - \\
\hline $\mathrm{P} 11 / \mathrm{E} / \mathrm{ns}$ & 6.8 & $<1^{\mathrm{e}}$ & $<1$ & $0.4(0.49)$ & $<1$ & $<1$ & $<1$ & - & - \\
\hline P12/E/L & 6.9 & $3.7^{f}(0.21)$ & $3.2(0.11)$ & $3.7(0.19)$ & $3.1(0.11)$ & $<1$ & $<1$ & - & + \\
\hline $\mathrm{P} 13 / \mathrm{E} / \mathrm{H}$ & 7.1 & $<1$ & $<1$ & $0.8(1.13)$ & $<1$ & $<1$ & $<1$ & - & - \\
\hline P14/SAM/L & 7.0 & $1.8(0.12)$ & $0.5(0.71)$ & $1.3(0.38)$ & $0.5(0.71)$ & $<1$ & $<1$ & - & - \\
\hline P15/SAM/L & 6.9 & $1.8(0.03)$ & $0.6(0.83)$ & $2.0(0.16)$ & $0.7(1.04)$ & $<1$ & $1.7^{\mathrm{f}}(0.37)$ & - & - \\
\hline P16/SAM/ns & 5.5 & $3.4(0.03)$ & $3.1(0.21)$ & $3.3(0.06)$ & $2.9(0.34)$ & $<1$ & $<1$ & - & - \\
\hline P17/AF/ns & 6.8 & $1.2(0.21)$ & $<1$ & $1.2(0.28)$ & $0.4(0.49)$ & $<1$ & $<1$ & - & - \\
\hline P18/AF/L & 5.4 & $0.9(0.34)$ & $<1$ & $1.0(0.43)$ & $0.4(0.49)$ & $<1$ & $<1$ & - & - \\
\hline P19/AF/L & 5.2 & $1.6(0.00)$ & $1.1(0.60)$ & $1.4(0.12)$ & $0.6(0.83)$ & $<1$ & $<1$ & - & - \\
\hline $\mathbf{P 2 0} / \mathrm{AS} / \mathrm{ns}$ & 6.9 & $1.7(0.17)$ & $1.1(0.12)$ & $1.6(0.19)$ & $0.7(0.21)$ & $<1$ & $1.7(0.25)$ & - & - \\
\hline P21/AS/ns & 6.9 & $0.5(0.71)$ & $<1$ & $<1$ & $0.7(0.49)$ & $<1$ & $<1$ & - & - \\
\hline P22/AS/ns & 7.2 & $1.2(0.71)$ & $<1$ & $0.4(0.49)$ & $<1$ & $<1$ & $<1$ & - & - \\
\hline P23/AS/H & 7.6 & $1.2(0.09)$ & $<1$ & $<1$ & $<1$ & $<1$ & $<1$ & - & - \\
\hline P24/AS/H & 7.3 & $2.6(0.06)$ & $1.4(0.30)$ & $2.6(0.14)$ & $2.4(0.15)$ & $<1$ & $<1$ & - & - \\
\hline P25/AS/ns & 5.3 & $2.0(0.03)$ & $<1$ & $1.9(0.05)$ & $0.7(0.99)$ & $<1$ & $<1$ & - & - \\
\hline Guidelines & & $<3.7$ & & & & $<\mathbf{1}$ & $<\mathbf{1 . 7}$ & Absent in 1g & Absent in $25 \mathrm{~g}$ \\
\hline
\end{tabular}

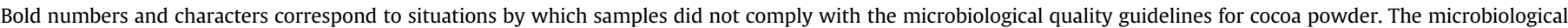
quality criteria are indicated.

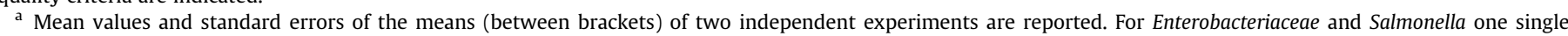
experiment was performed.

b E- Europe, SAM- South America, AF- Africa, AS- Asia.

c Fat content: Low (L)-10-12\% (w/w); High (H)- 20-22\% (w/w); not specified (ns) in the package.

d + - - presence/absence.

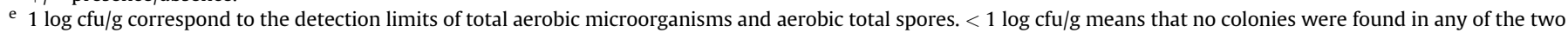
independent experiments.

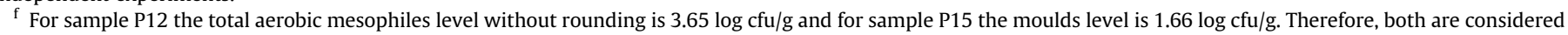
(just) to comply with the guidelines. 
Table 2

Estimated average levels (log cfu/g) and Most Probable Number (MPN) of mesophilic and thermophilic thermoresistant spores in cocoa powder samples ${ }^{\mathrm{a}}$

\begin{tabular}{|c|c|c|c|c|c|c|}
\hline Incubation $\left({ }^{\circ} \mathrm{C}\right)$ & Heat-treatment & $\log \mathrm{cfu} / \mathrm{g}$ & $\log \mathrm{MPN} / \mathrm{g}$ & 95\% confidence limits & Sample code & Strain code of studied isolates \\
\hline \multirow[t]{18}{*}{30} & $100{ }^{\circ} \mathrm{C}-10 \mathrm{~min}$ & 1.0 & 0.6 & {$[-0.30 ; 1.41]$} & P20 & M103, M104 \\
\hline & & 1.2 & 1.3 & {$[0.85 ; 1.77]$} & P8 & M21, M22 \\
\hline & & 1.2 & 1.3 & {$[0.85 ; 1.77]$} & P15 & M100, M101 \\
\hline & & 1.2 & 1.3 & {$[0.85 ; 1.77]$} & P24 & M107, M108, M109 \\
\hline & & 1.4 & 1.6 & {$[0.99 ; 2.27]$} & P10 & M31, M32, M34, M35 \\
\hline & & 1.5 & 1.6 & {$[0.99 ; 2.27]$} & P9 & M25, M27, M29, M30 \\
\hline & & 1.6 & 2.0 & {$[1.35 ; 2.59]$} & P4 & M13, M14, M16, M17 \\
\hline & & 1.7 & 2.0 & {$[1.35 ; 2.59]$} & P12 & M38, M40, M41, M42 \\
\hline & & 1.8 & 2.2 & {$[1.65 ; 2.70]$} & P2 & M1, M2, M4, M5, M7, M8 \\
\hline & $100{ }^{\circ} \mathrm{C}-30 \mathrm{~min}$ & $<1^{\mathrm{b}}$ & 0.6 & {$[-0.30 ; 1.41]$} & P15 & M110 \\
\hline & & 1.0 & 1.0 & {$[0.34 ; 1.59]$} & P12 & M70, M71 \\
\hline & & 1.3 & 1.0 & {$[0.34 ; 1.59]$} & P4 & M67, M68, M69 \\
\hline & & 1.4 & 1.3 & {$[0.85 ; 1.77]$} & P2 & M63, M64, M65, M66 \\
\hline & $108^{\circ} \mathrm{C}-30 \mathrm{~min}$ & $<1$ & 0.6 & {$[-0.30 ; 1.41]$} & P4 & M90 \\
\hline & & 1.0 & 1.0 & {$[0.34 ; 1.59]$} & P2 & M88, M89 \\
\hline & $110^{\circ} \mathrm{C}-10 \mathrm{~min}$ & 1.0 & 0.6 & {$[-0.30 ; 1.41]$} & P2 & M94, M95 \\
\hline & $120{ }^{\circ} \mathrm{C}-10 \mathrm{~min}$ & 0.7 & 0.6 & {$[-0.30 ; 1.41]$} & P2 & M98 \\
\hline & $150{ }^{\circ} \mathrm{C}-10 \mathrm{~min}$ & 0.7 & 0.6 & {$[-0.30 ; 1.41]$} & $\mathrm{P} 2$ & M112 \\
\hline \multirow[t]{6}{*}{55} & $100{ }^{\circ} \mathrm{C}-10 \mathrm{~min}$ & $<1$ & 0.6 & {$[-0.30 ; 1.41]$} & P15 & TT102 \\
\hline & & $<1$ & 0.6 & {$[-0.30 ; 1.41]$} & P20 & TT106 \\
\hline & & 1.9 & 1.6 & {$[0.99 ; 2.26]$} & P12 & ТT45, ТT46, ТT50, ТT52, ТТ53 \\
\hline & $100{ }^{\circ} \mathrm{C}-30 \mathrm{~min}$ & 1.9 & 1.6 & {$[0.99 ; 2.26]$} & P12 & TT77, ТT80 \\
\hline & $108^{\circ} \mathrm{C}-30 \mathrm{~min}$ & 1.3 & 0.9 & {$[0.26 ; 1.47]$} & P12 & ТT92, ТТ93 \\
\hline & $110^{\circ} \mathrm{C}-10 \mathrm{~min}$ & 1.0 & 0.6 & {$[-0.30 ; 1.41]$} & P12 & ТТ96, ТТ97 \\
\hline
\end{tabular}

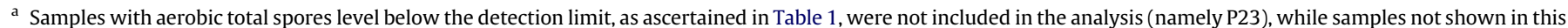
table had all MPN tubes negative, corresponding to an MPN level below $0.5 \log$ MPN/g and a higher confidence limit for the $95 \%$ confidence interval of 0.98 log MPN/g.

b $1 \mathrm{log} \mathrm{cfu} / \mathrm{g}$ is the detection limit of the plate count based method.

TT50, the sporulation was not promoted, in the case of strain M13, or to a very insignificant level, in the case of strain TT50 (occasional spores were seen in several microscopic fields). For all other strains isolated at $55^{\circ} \mathrm{C}$, higher spore yields were obtained at either $50^{\circ} \mathrm{C}$ or $45{ }^{\circ} \mathrm{C}$. For strains isolated at $30{ }^{\circ} \mathrm{C}$ higher yield or faster spore production took place at $37^{\circ} \mathrm{C}$.

Fig. 1 presents a phylogenetic tree based on the $16 \mathrm{~S}$ rDNA sequence of the isolates (contigs varied between 1434 and 1490 bp). Four groups could be identified: group I, group II and group III, constituted, respectively, of members of $B$. subtilis complex, $B$. licheniformis and $B$. cereus complex, and group IV by the single species lineages of Bacillus simplex and Geobacillus spp. High percentages of similarities with known sequences in GenBank (98-100\%) were found for the majority of the isolates (Supplementary data). In the case of members of $B$. cereus group these values were somewhat lower, but the BLAST search with sequences derived from the amplification with the forward primer resulted in $99 \%$ similarity to B. cereus strains.

For 7 strains within the B. subtilis complex, $99 \%$ of similarity was found with Bacillus amyloliquefaciens strains in the GenBank database. Considering that D-lactose fermentation is restricted among B. subtilis (Nakamura, 1987) and that B. amyloliquefaciens strains have a limited ability to use inulin (Logan and Berkeley, 1984), the isolates were presumptively identified as B. amyloliquefaciens. All the other strains were identified as members of $B$. subtilis complex (Roberts et al., 1994, 1996). A high degree of 16S rDNA similarity exists among species of the $B$. cereus group as well (Lechner et al., 1998; Nakamura, 1998). However, none of the isolates had the typical Bacillus mycoides colony morphology (Di Franco et al., 2002) and all of them were motile, which allowed the exemption of species assignment as B. mycoides or B. anthracis (Sneath, 1986).

The $16 \mathrm{~S}$ rDNA sequence for strain TT50 resulted in $98 \%$ similarity with sequences mainly from Geobacillus thermoleovorans, Geobacillus kaustophilus and Geobacillus caldotenax. Nonetheless, outcomes with equal similarity were also obtained for G. stearothermophilus, with which a distinct API 50 CHB profiles had been obtained (Supplementary data). Based on the gathered information, strain TT50 was solely classified as a member of the Geobacillus genus.
The AFLP analysis of the isolates yielded a total of 261 markers, of which 101 were obtained with the primer combination EcoRI-A/ MseI-C and 161 with the primer combination EcoRI-C/MseI-G. The number of fragments per strain varied between 50 and 83 for the first primer combination and from 37 to 65 for the second. The clustering of the AFLP profiles is depicted in Fig. 2. The tree displayed a similar topology with the one obtained based on the $16 \mathrm{~S}$ rDNA sequences, with the difference that a subcluster of $B$. amyloliquefaciens, encompassing, as well, isolates M16 and M7 emerged. Twenty-eight polymorphic profiles were obtained within the B. subtilis complex (thirty-one strains), nine for B. amyloliquefaciens (nine strains), eleven for $B$. licheniformis (thirteen strains) and three for $B$. cereus group (six strains).

\subsection{Thermoresistant spores heat-resistance properties}

Fig. 3 displays the comparative survival of the spore crops at $110^{\circ} \mathrm{C}$ for $5 \mathrm{~min}$. The spores revealed substantially different heatresistance: 24 spore crops out of 60 , including the type strain of B. subtilis, were reduced to levels below the detection limit (group C); eight were highly heat-resistant, with a reduction lower than 1 log $\mathrm{cfu} / \mathrm{ml}$ (group A); and for the remaining crops, reductions ranged between 1.3 and $5.0 \log \mathrm{cfu} / \mathrm{ml}$ (group B). Strain M112 spores had an exceptionally high heat-resistance, showing rather an increase in spore counts as result of the heat-treatment.

For a selection of strains of the B. subtilis complex, representative of the 3 established heat-resistance groups, including one B. amyloliquefaciens strain, thermal kinetic parameters were determined. Fig. 4 shows the survival curves for two of the most heat-resistant spore crops. In general, the survival plots yielded straight lines, except for strain M112 spores, which consistently displayed activation shoulders in the range $117.5-125^{\circ} \mathrm{C}$.

Based on the criteria whether the confidence interval for the $n$-value of the Weibull model contained the value 1 (indicating that the Weibull model could be reduced to a log-linear model) and analysis of the MSE $E_{\text {model }}$ values (the lower, the better the fit of the applied model), the fitting performance of the log-linear and Weibull 

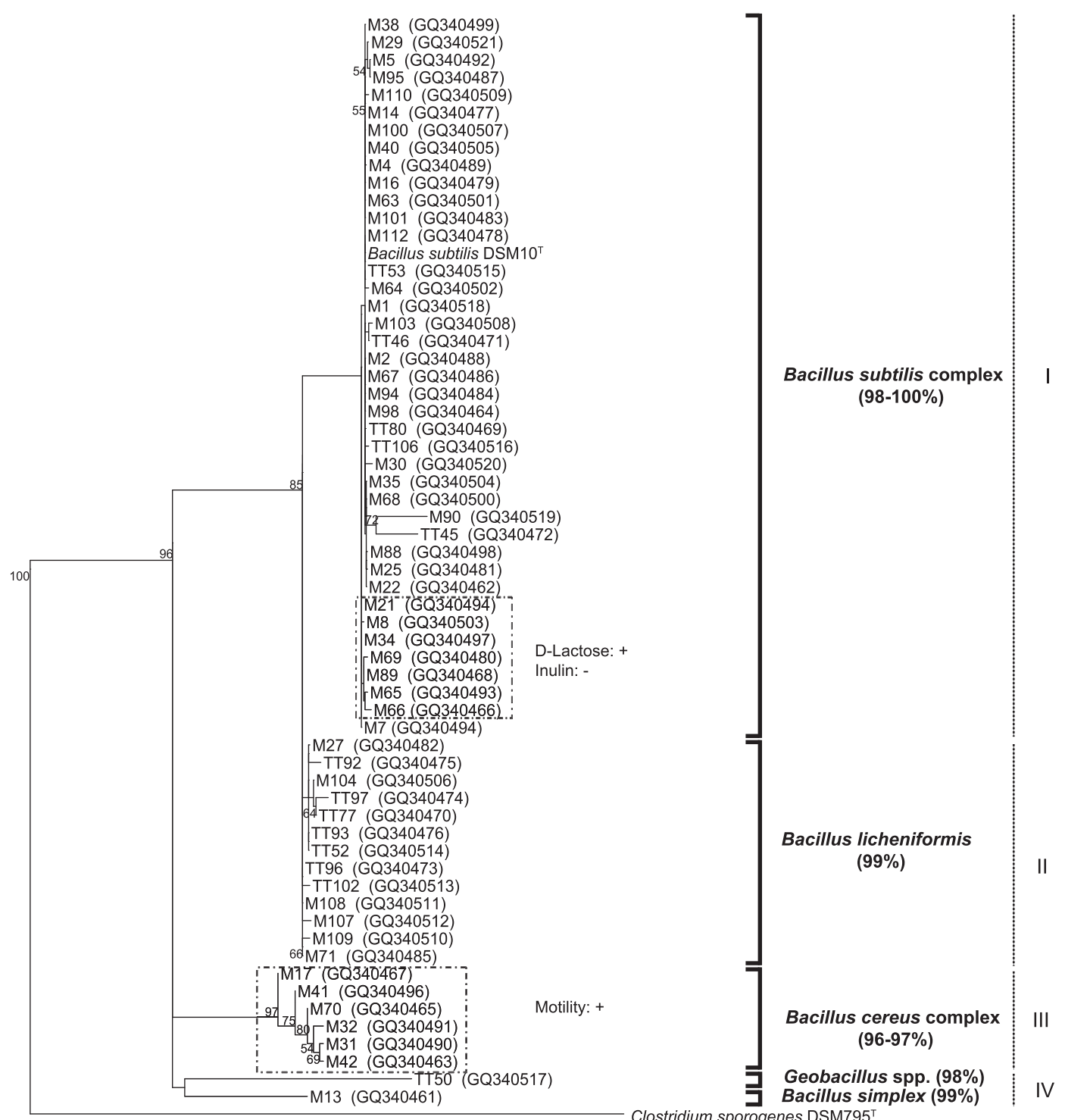

Scale:

Clostridium sporogenes DSM795

Fig. 1. Phylogenetic tree of the thermoresistant spore-forming isolates based on nearly full $16 \mathrm{~S}$ rRNA gene sequences. The phylogram was constructed with the tree builder tool in the Ribosomal Database Project II (RDP). The bootstrap values are based on 100 bootstrap replications and are not shown on the nodes with lower than $50 \%$ bootstrap support. The scale bar (0.1) represents the number of nucleotide substitutions per sequence position. The sequence of Clostridium sporogenes DSM $795^{\mathrm{T}}$ (type strain) was used as an outgroup. The GenBank accession numbers assigned to nucleotide sequences determined in this study, as well as the percentages of similarity with known sequences in GenBank are given between brackets. Lactose positive means that the isolates were able to ferment lactose, while inulin negative indicates the inability of its fermentation as ascertained by the API 50 CHB system. A positive motility indicates a diffuse growth spreading from the line of inoculation in the motility agar medium prepared as described in the materials and methods.

models was compared. The log-linear model was found to be adequate to fit the survival data in 18 out of 23 cases. For this reason, this model was chosen to globally characterize and compare the inactivation profile for all the spore crops (Table 3). Strain M112 spores were the most heat-resistant with an estimated $\mathbf{D}$-value at $130^{\circ} \mathrm{C}$ of $0.18 \mathrm{~min}$. Strains M65 and M95 spores were the most heatsensitive and had comparable $D$-values in the range $100^{\circ} \mathrm{C}-105^{\circ} \mathrm{C}$. The $z$-values varied between $6.4^{\circ} \mathrm{C}$ and $11.9^{\circ} \mathrm{C}$, respectively, for M65 and M95 spore crops (Table 3 and Fig. 5). For the three most heatresistant spore crops, the estimated $z$-value varied between $6.5^{\circ} \mathrm{C}$ and $8.4{ }^{\circ} \mathrm{C}$. The regression coefficients for the $z$-value estimation were in general high (0.98-0.99), with exception for strains M65 and M112 spore crops, where these values were, respectively, 0.96 and 0.79 (Table 3 ).

\section{Discussion}

The trajectory of cocoa beans in the cocoa chain, determines not only the microbial load, but also the diversity and physiological properties of the microorganisms associated with cocoa beans derived products, specifically cocoa powder.

It was found that commercial cocoa powder samples can have substantially different microbiological quality. For example, five of the analysed cocoa powder samples had extremely low levels of total aerobic mesophiles (lower than $1 \mathrm{log}$ cfu/g or below the detection limit), while for one sample (P12) detectable levels up till $3.7 \mathrm{log} \mathrm{cfu} / \mathrm{g}$ were registered. The latter, in conjunction with the detection of Enterobacteriaceae, moulds and Salmonella are indications of post-roasting contamination. In particular, the detection 


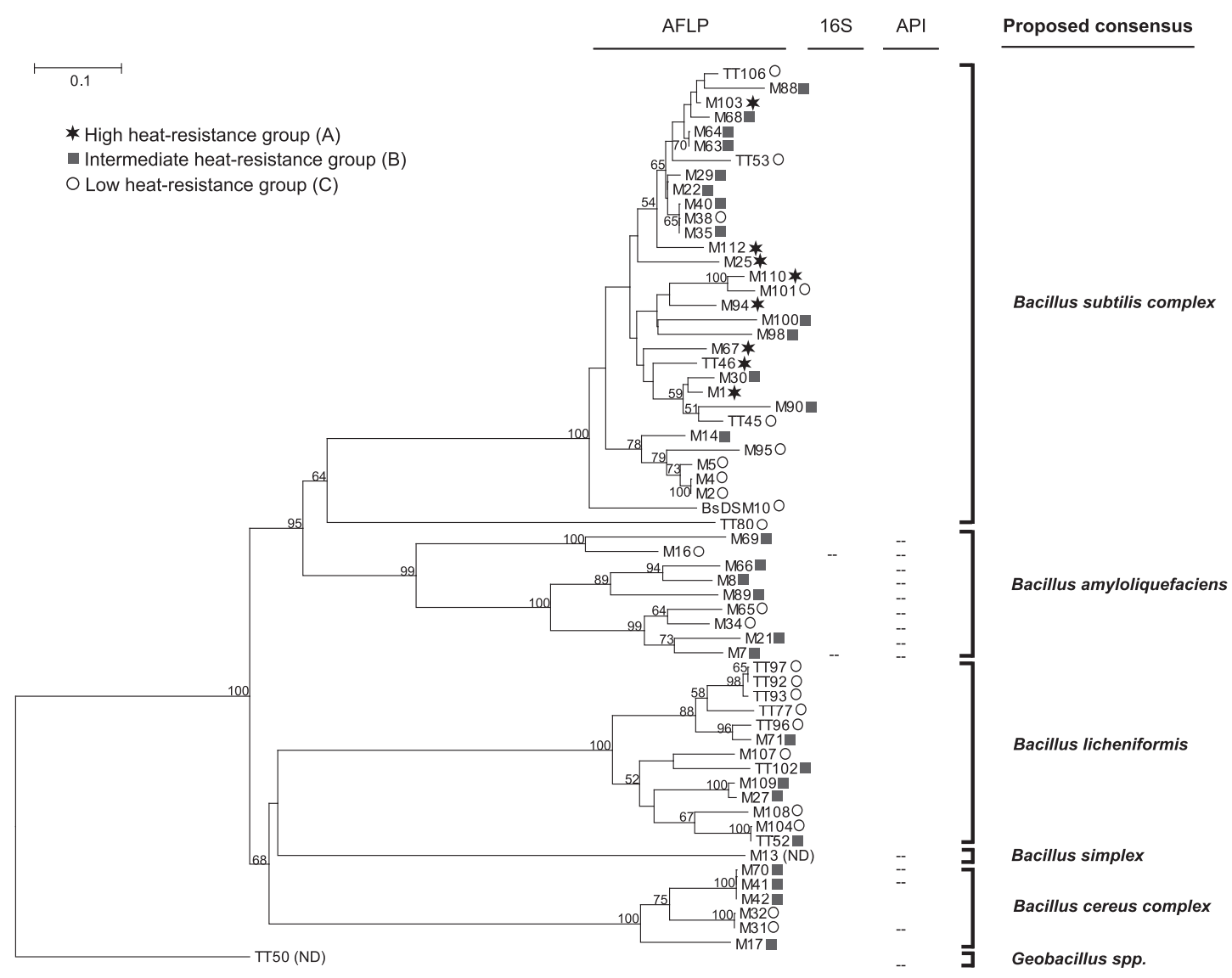

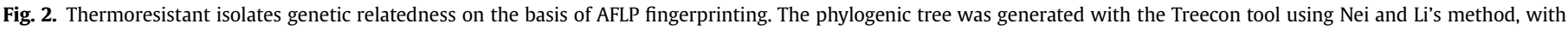

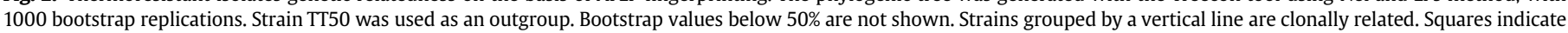

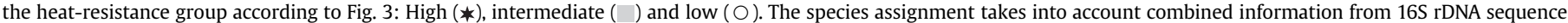

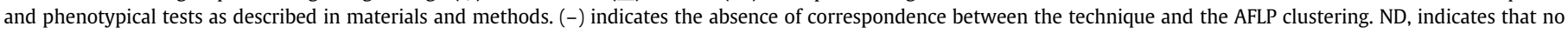
spores could be produced. The abbreviations ' $16 \mathrm{~S}$ ' and 'API' show the correspondence of the $16 \mathrm{~S}$ rDNA and API 50 CHB with the AFLP proposed consensus, respectively.

of Salmonella in one of the twenty-five samples is a matter of attention, due to the implication of low levels of Salmonella in outbreaks linked to chocolate (Werber et al., 2005).

For a few samples, namely P2, P3 and P15, the level of aerobic Total Spores (TS) was observed to be higher than that of Total Aerobic Microorganisms (TAM) (Table 1). This difference was particularly evident in sample P2, where, not only, a higher number of aerobic Thermoresistant spores (ThrS) were isolated, but also, the most heat-resistant spores were present (namely spores from strain M112) (Table 2). This difference could be explained by the phenomenon of spore activation, indicating the predominance of spore-formers in these cocoa powder samples.

With respect to the occurrence of ThrS, these were detected in $36 \%$ of the samples, with levels which ranged from below $5 \%$ of TS (such as in the case of samples P12 and P24) to levels approximately the same as TS (for instance sample P8).

ThrS were isolated from 'Alkalised cocoa powders' ( $\mathrm{pH} 7-8$ ), but not from 'Natural cocoa powders' ( $\mathrm{pH} \mathrm{5-6)} \mathrm{(Table} 1$ and 2). Whether this was a fortuitous outcome or influenced by the $\mathrm{pH}$ at which the cocoa powder suspension was heated, is something that would need to be investigated in a systematic way.

Members of $B$. subtilis complex were the predominant thermoresistant spore-forming species, with a fraction of $65.6 \%(40 / 61)$ of the total isolates, of which $14.8 \%$ (9/61) could be identified as B. amyloliquefaciens. Geobacillus spp. strain TT50 was the only true thermophilic strain in our collection. This is consistent with the reported Bacilli diversity during cocoa beans fermentation, where the participation of thermophilic species appears to be sporadic (Lima et al., in press).

The combination of the heat-resistance profile of the thermoresistant strains (Fig. 3), with the AFLP clustering pattern (Fig. 2) provided a range of thermal resistance and genotypic correspondences. Strains from B. subtilis complex formed the most heatresistant spores and some of these isolates clustered in the same clade, for example, M67-M1. However, clades formed by strains producing spores with considerable different heat-resistance were also found, for instance, M30-TT45, M110-M101 and TT106-M68. Since the spores were produced under the same conditions, the nature of the underlying difference of spores heat-resistance should be bound to genetic factors that were not visible in the AFLP profiling. This genotypic diversity needs to be taken into account in strategies aimed at designing biomarkers for the detection and control of thermoresistant spore-formers within the food industry. Strikingly, also strains clonally related had spores with significantly different heat-resistance. This was the case of strains of $B$. subtilis complex M40/M38/M35 and strains M104/TT52 belonging to $B$. licheniformis species. It is conceivable that homoplasy and collision events in the AFLP profile might have hampered the discrimination of these strains (Meudt and Clarke, 2007), or that the strains constitute variants of the same strain (Avery, 2006). The approach to fully understand such phenomenon would require whole genome sequencing.

Some of the strains with a putative clonal origin, were isolated from samples of different countries or continents, such as B. subtilis 


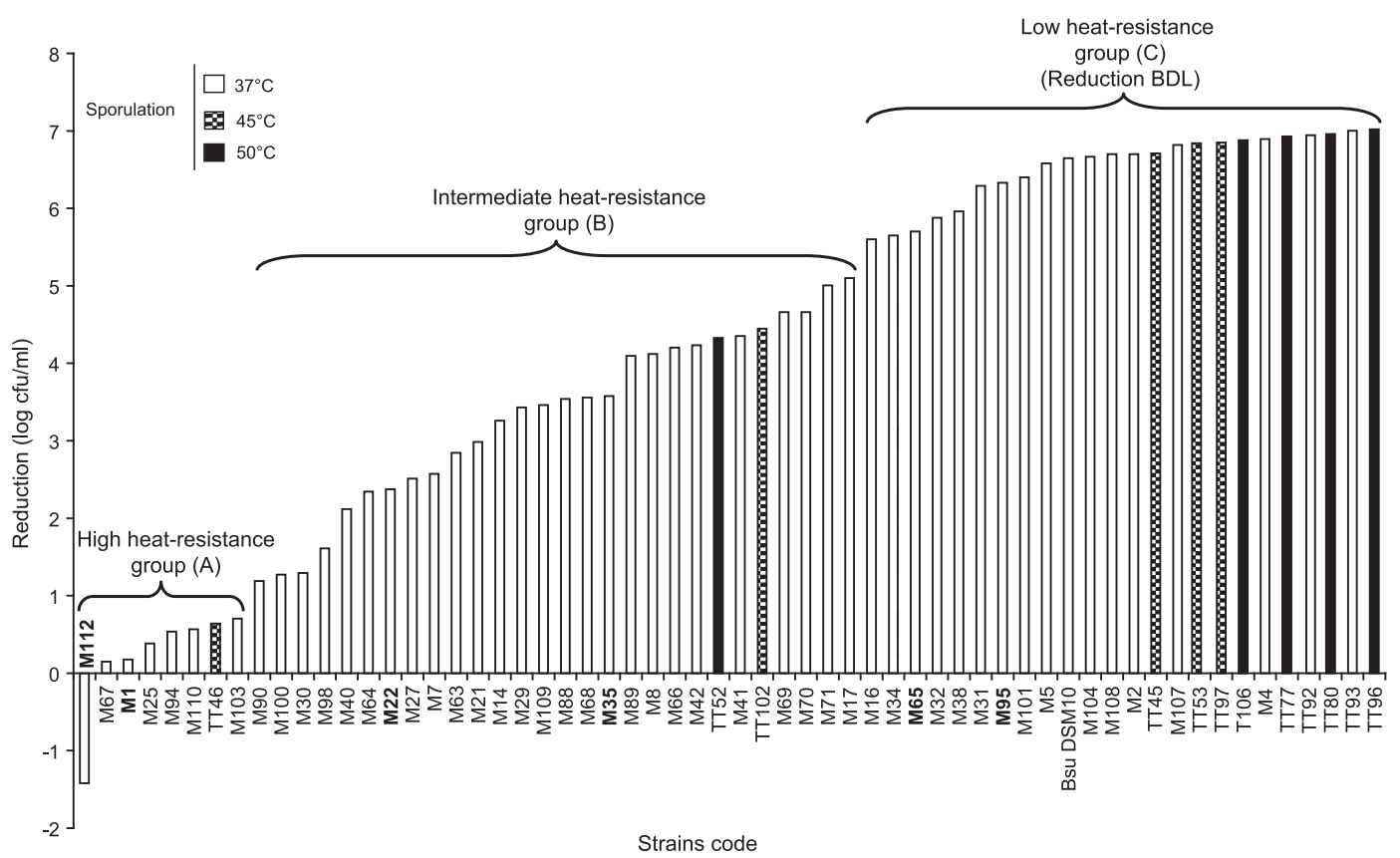

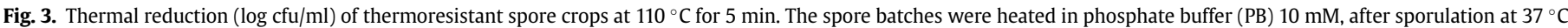

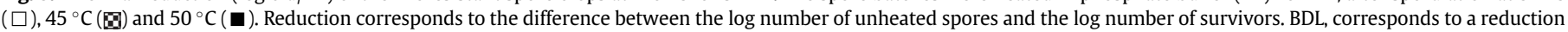
Below the Detection Limit of $1.7 \mathrm{log} \mathrm{cfu} / \mathrm{ml}$. Bsu DSM10 represents the type strain Bacillus subtilis DSM10. D and $z$-values were determined for the strains highlighted in bold.

complex strains M40-M35, and B. licheniformis strains M104-TT52. This could be an indication of a wide geographical distribution of the genotype in question, but the fact that cocoa powder is made up of blends of cocoa beans from different countries, together with the uncertainty of the clonal origin, imply that these observations must be interpreted carefully.

Another outcome from our results was the observation that after resporulation of the isolates, some spore crops displayed lower

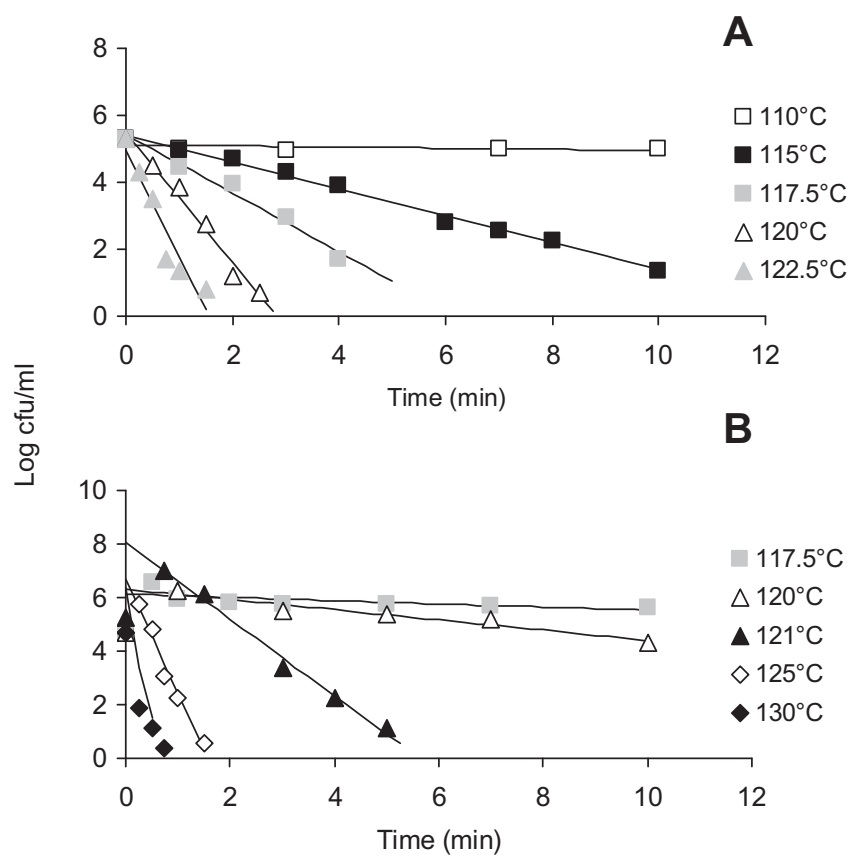

Fig. 4. Survival curves of Bacillus subtilis complex spores crops of strains M1 (A) and M112 (B) in phosphate buffer $10 \mathrm{mM}$ at $110^{\circ} \mathrm{C}(\square), 115^{\circ} \mathrm{C}(\boldsymbol{\square}), 117.5^{\circ} \mathrm{C}(\square), 120^{\circ} \mathrm{C}(\triangle)$ $121^{\circ} \mathrm{C}(\Delta), 122.5^{\circ} \mathrm{C}(\triangle), 125^{\circ} \mathrm{C}(\diamond)$ and $130^{\circ} \mathrm{C}(\diamond)$. The points correspond to average of duplicate plate count determinations. heat-resistance than expected, considering their isolation conditions (for instance, spores of B. subtilis complex strains M89 and M95 and B. licheniformis strains TT92, TT93, TT97 and TT96). This is not a new observation (Huemer et al., 1998). Different factors could explain this phenomenon, namely the fact that heat-resistance is

Table 3

$D$ and $z$-values calculated using the log-linear model for spores of $B$. subtilis complex strains in phosphate buffer $10 \mathrm{mM}$.

\begin{tabular}{|c|c|c|c|c|c|c|c|}
\hline Strain & $\begin{array}{l}\text { Temperature } \\
\left({ }^{\circ} \mathrm{C}\right)\end{array}$ & $\begin{array}{l}D \text {-value } \\
\text { (min) }\end{array}$ & $r^{2}$ & $\mathrm{MSE}_{\text {model }}$ & $z\left({ }^{\circ} \mathrm{C}\right)^{\mathrm{a}}$ & $r^{2}$ & $\begin{array}{l}D_{110}{ }^{\circ} \mathrm{C} \\
(\mathrm{min})\end{array}$ \\
\hline \multirow[t]{3}{*}{ M65 } & 95 & 18.4 & 0.849 & 0.00931 & 6.40 & 0.956 & 0.0669 \\
\hline & 100 & 1.57 & 0.935 & 0.164 & - & - & - \\
\hline & 105 & 0.505 & 0.969 & 0.185 & - & - & - \\
\hline \multirow[t]{3}{*}{ M95 } & 100 & 1.32 & 0.997 & 0.0216 & 11.9 & 0.978 & 0.183 \\
\hline & 105 & 0.425 & 0.973 & 0.190 & - & - & - \\
\hline & 107.5 & 0.323 & 0.639 & 2.62 & - & - & - \\
\hline \multirow[t]{3}{*}{ M35 } & 100 & 24.6 & 0.756 & 0.0148 & 7.94 & 0.994 & 1.44 \\
\hline & 110 & 1.74 & 0.976 & 0.102 & - & - & - \\
\hline & 115 & 0.297 & 0.995 & 0.0251 & - & - & - \\
\hline \multirow[t]{4}{*}{ M22 } & 110 & 2.64 & 0.996 & 0.0123 & 8.35 & 0.991 & 2.49 \\
\hline & 115 & 0.596 & 0.983 & 0.0613 & - & - & - \\
\hline & 117.5 & 0.276 & 0.992 & 0.0509 & - & - & - \\
\hline & 120 & 0.179 & 0.970 & 0.177 & - & - & - \\
\hline \multirow[t]{5}{*}{ M1 } & 110 & 57.3 & 0.263 & 0.0201 & 8.24 & 0.990 & 9.51 \\
\hline & 115 & 2.48 & 0.994 & 0.0125 & - & - & - \\
\hline & 117.5 & 1.14 & 0.976 & 0.0263 & - & - & - \\
\hline & 120 & 0.516 & 0.982 & 0.0762 & - & - & - \\
\hline & 122.5 & 0.315 & 0.907 & 0.376 & - & - & - \\
\hline \multirow[t]{5}{*}{ M112 } & 117.5 & 16.4 & 0.491 & 0.0559 & 6.47 & 0.785 & 111 \\
\hline & 120 & 5.23 & 0.948 & 0.0354 & - & - & - \\
\hline & 121 & 0.700 & 0.994 & 0.0578 & - & - & - \\
\hline & 125 & 0.235 & 0.986 & 0.0944 & - & - & - \\
\hline & 130 & 0.184 & 0.874 & 0.667 & - & - & - \\
\hline
\end{tabular}

${ }^{a} D$-values 2.5 times higher than the experimental duration (12 min) were not included for the determination of the $z$-values.

$\mathrm{b}$ The kinetic parameters for the spore crop of M112 in the range $117.5-125^{\circ} \mathrm{C}$ are calculated without $N(0)$. 


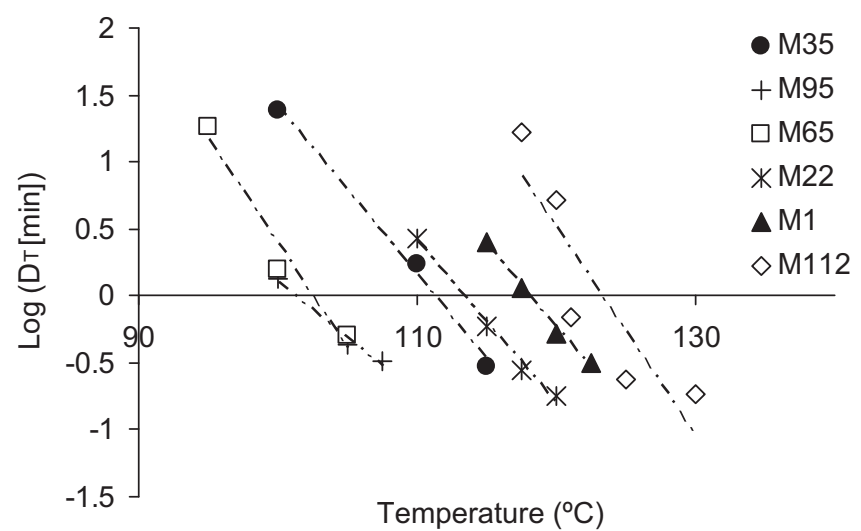

Fig. 5. Least-square regression of log-transformed estimated $D$-values as function of the temperature for Bacillus subtilis complex spores in phosphate buffer $10 \mathrm{mM}$. $D$-values 2.5 times higher than the experimental duration were excluded. Spore crop of

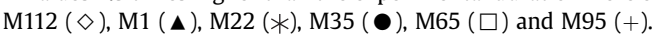

not an absolute spore property, but dependent on the sporulation conditions and maturation circumstances after spores release from the mother cell (Bender and Marquis, 1985; Hornstra et al., 2009). Moreover, the occurrence of cell cultures prone to phenotypical heterogeneity, as mentioned before, could also influence the range of spores heat-resistance.

Six strains belonging to the $B$. subtilis complex, including one strain identified as B. amyloliquefaciens, were chosen to determine the thermal kinetic parameters $D$ and $z$-values and illustrate the disparity in heat-resistance that can be found within this group (Table 3). The comparison of the $D_{\text {ref }}$ at $110{ }^{\circ} \mathrm{C}$ shows the large difference in the heat-resistance of the strains spore crop. Strain M112 spores were the most heat-resistant under the studied conditions, with an estimated $D_{110^{\circ} \mathrm{C}}$ of $111 \mathrm{~min}$. Its spore crop heatresistance was 7 times higher than the one of another highly heatresistant $B$. subtilis strain (A163), which had been isolated from a sterilised peanut chicken soup $\left(D_{120^{\circ} \mathrm{C}}\right.$ of $\left.0.7 \mathrm{~min}\right)$ (Kort et al., 2005; Oomes et al., 2007). Though, to precisely compare the heat-resistance of these spores, they would have to be produced under the same conditions.

The persistence of shoulders in the inactivation profile of strain M112 may be explained by spores activation. Pre-activation treatments to avoid shoulders were deliberately not applied, in order to characterise the spore crop resilience at UHT-temperature range, for which the estimated $D$-values can be useful in the processing of cocoa-derived products.

We concluded that spores from the B. subtilis complex have the potential of surviving subsequent preservation treatments, challenging downstream product quality stability, such as chocolate milk.

It can be expected that the systematic study of highly heatresistant spores in cocoa powder can contribute to better targeted processing and quality optimisation of cocoa-derived products.

\section{Acknowledgements}

L. Lima was supported by the Portuguese Foundation of Science and Technology (grant SFRH/BD721929/2005).

We are grateful to the cocoa powder samples suppliers and to Monika Golinska and Utku Ataman for technical assistance. We thank Suus Oomes (Unilever Research Laboratory, Vlaardingen) for her help setting up the heat-inactivation assay and Fien Meijer-Dekens for running the AFLP gels. Menno van der Voort is acknowledged for critically reading the manuscript.

\section{Appendix. Supplementary material}

Supplementary data related to this article can be found online at doi:10.1016/j.fm.2010.11.011.

\section{References}

Altschul, S., Gish, W., Miller, W., Myers, E., Lipman, D., 1990. Basic local alignment search tool. J. Mol. Biol. 215, 403-410.

Anon., 1981. Codex Alimentarius. Codex Standards for Cocoa Products and Chocolate, Standard 105-1981, rev. 1-2001, p. 7.

Avery, S.V., 2006. Microbial cell individuality and the underlying sources of heterogeneity. Nat. Rev. Microbiol. 4, 577-587.

Barrile, J.C., Ostovar, K., Keeney, P.G., 1971. Microflora of cocoa beans before and after roasting at $150^{\circ} \mathrm{C}$. J. Milk Food Technol. 34, 369-371.

Bender, G.R., Marquis, R.E., 1985. Spore heat resistance and specific mineralization. Appl. Environ. Microbiol. 50, 1414-1421.

Blodgett, R., 2006. Most Probable Number (MPN) from Serial Dilutions. Bacteriological Analytical Manual Online, 8th ed. http://www.fda.gov/Food/ ScienceResearch/LaboratoryMethods/BacteriologicalAnalyticalManualBAM/ ucm109656.htm\#tables (Retrieved 02.07.08).

Cazemier, A.E., Wagenaars, S.F.M., Ter Steeg, P.F., 2001. Effect of sporulation and recovery medium on the heat resistance and amount of injury of spores from spoilage bacilli. J. Appl. Microbiol. 90, 761-770.

Di Franco, C., Beccari, E., Santini, T., Pisaneschi, G., Tecce, G., 2002. Colony shape as a genetic trait in the pattern-forming Bacillus mycoides. BMC Microbiol. 2 (33), 1-15.

Dijk, R., van den Berg, D., Beumer, R., de Boer, E., Dijkstra, A., Kalkman, P., Stegeman, H., Uyttendaele, M., Veenendaal, H., 2007. Microbiologie van voedingsmiddelen methoden, principes en criteria. Noordervliet media B.V., Houten, The Netherlands.

Edwards, U., Rogall, T., Blocker, H., Emde, M., Bottger, E.C., 1989. Isolation and direct complete nucleotide determination of entire genes. Characterization of a gene coding for $16 \mathrm{~S}$ ribosomal RNA. Nucleic Acids Res. 17, 7843-7853.

Gabis, D.A., Langlois, B.E., Rudnick, A.W., 1970. Microbiological examination of cocoa powder. Appl. Microbiol. 20, 644-645.

Gregersen, T., 1978. Rapid method for distinction of Gram-negative from Grampositive bacteria. Eur. J. Appl. Microbiol. Biotechnol. 5, 123-127.

Hornstra, L.M., Ter Beek, A., Smelt, J.P., Kallemeijn, W.W., Brul, S., 2009. On the origin of heterogeneity in (preservation) resistance of Bacillus spores: input for a 'systems' analysis approach of bacterial spore outgrowth. Int. J. Food Microbiol. 134, 9-15.

Huemer, I.A., Klijn, N., Vogelsang, H.W.J., Langeveld, L.P.M., 1998. Thermal death kinetics of spores of Bacillus sporothermodurans isolated from UHT milk. Int. Dairy J. 8, 851-855.

Kamphuis, H., 2009. Production and quality standards of cocoa mass, cocoa butter and cocoa powder. In: Beckett, S.T. (Ed.), Industrial Chocolate Manufacture and Use. Blackwell Publishing Ltd., Oxford, pp. 121-141.

Kort, R., O’Brien, A.C., van Stokkum, I.H., Oomes, S.J., Crielaard, W., Hellingwerf, K.J., Brul, S., 2005. Assessment of heat resistance of bacterial spores from food product isolates by fluorescence monitoring of dipicolinic acid release. Appl. Environ. Microbiol. 71, 3556-3564.

Lechner, S., Mayr, R., Francis, K.P., Pruss, B.M., Kaplan, T., WiessNer-Gunkel, E., Stewart, G.S.A.B., Scherer, S., 1998. Bacillus weihenstephanensis sp. nov. is a new psychrotolerant species of the Bacillus cereus group. Int. J. Syst. Bacteriol. 48, 1373-1382.

Lima, L.J.R., Almeida, M.H., Nout, M.J.R., and Zwietering, M.H., in press. Theobroma cacao L., "The food of the gods": quality determinants of commercial cocoa beans, with particular reference to the impact of the fermentation. Crit. Rev. Food Sci. Nutr.

Logan, N.A., Berkeley, R.C.W., 1984. Identification of Bacillus strains using the API system. J. Gen. Microbiol. 130, 1871-1882.

Mafart, P., Couvert, O., Gaillard, S., Leguerinel, I., 2002. On calculating sterility in thermal preservation methods: application of the Weibull frequency distribution model. Int. J. Food Microbiol. 72, 107-113.

Meudt, H.M., Clarke, A.C., 2007. Almost forgotten or latest practice? AFLP applications, analyses and advances. Trends Plant Sci. 12, 106-117.

Mossel, D.A.A., Meursing, E.H., Slot, H., 1974. An investigation on the numbers and types of aerobic spores in cocoa powder and whole milk. Neth. Milk Dairy J. 28, 149-154.

Myburg, A.A., Remington, D.L., O'Malley, D.M., Sederoff, R.R., Whetten, R.W., 2001. High-throughput AFLP analysis using infrared dye-labeled primers and an automated DNA sequencer. Biotechniques 30, 348-357.

Nakamura, L.K., 1987. Deoxyribonucleic acid relatedness of lactose-positive Bacillus subtilis strains and Bacillus amyloliquefaciens. Int. J. Syst. Bacteriol. 37, 444-445.

Nakamura, L.K., 1998. Bacillus pseudomycoides sp. nov. Int. J. Syst. Bacteriol. 48, 1031-1035.

Oh, M.H., Cox, J.M., 2009. Toxigenic bacilli associated with food poisoning. Food Sci. Biotechnol. 18, 594-603.

Oomes, S.J.C.M., van Zuijlen, A.C.M., Hehenkamp, J.O., Witsenboer, H., van der Vossen, J.M.B.M., Brul, S., 2007. The characterisation of Bacillus spores occurring in the manufacturing of(low acid) canned products. Int. J. Food Microbiol.120, 85-94.

Park, C.E., Stankiewicz, Z.K., Rayman, M.K., Hauschild, A.H.W., 1979. Inhibitory effect of cocoa powder on the growth of a variety of bacteria in different media. Can. J. Microbiol. 25, 233-235.

Roberts, M.S., Nakamura, L.K., Cohan, F.M., 1994. Bacillus mojavensis sp. nov., distinguishable from Bacillus subtilis by sexual isolation, divergence in DNA sequence, and differences in fatty acid composition. Int. J. Syst. Bacteriol. 44, 256-264. 
Roberts, M.S., Nakamura, L.K., Cohan, F.M., 1996. Bacillus vallismortis sp. nov., a close relative of Bacillus subtilis, isolated from soil in Death Valley, California. Int. J. Syst. Bacteriol. 46, 470-475.

Schwan, R.F., Wheals, A.E., 2004. The microbiology of cocoa fermentation and its role in chocolate quality. Crit. Rev. Food Sci. Nutr. 44, 205-221.

Sneath, P.H.A., 1986. Endospore-forming Gram-positive rods and cocci. In: Sneath, P.H.A., Mair, N.S., Sharpe, M.E., Holt, J.G. (Eds.), Bergey's Manual of Systematic Bacteriology. Williams \& Wilkins, Baltimore, Md, pp. 1104-1207.

Stackebrandt, E., Goebel, B.M., 1994. Taxonomic note: a place for DNA-DNA reassociation and 16S rRNA sequence analysis in the present species definition in bacteriology. Int. J. Syst. Bacteriol. 44, 846-849.
Van de Peer, Y., De Wachter, R., 1994. TREECON for Windows: a software package for the construction and drawing of evolutionary trees for the Microsoft Windows environment. Comp. Appl. Biosci. 10, 569-570.

Vos, P., Hogers, R., Bleeker, M., Reijans, M., Van de Lee, T., Hornes, M., Frijters, A. Pot, J., Peleman, J., Kuiper, M., Zabeau, M., 1995. AFLP: a new technique for DNA fingerprinting. Nucleic Acids Res. 23, 4407-4414.

Werber, D., Dreesman, J., Feil, F., van Treeck, U., Fell, G., Ethelberg, S., Hauri, A.M. Roggentin, P., Prager, R., Fisher, I.S.T., Behnke, S.C., Bartelt, E., Weise, E., Ellis, A., Siitonen, A., Andersson, Y., Tschäpe, H., Kramer, M.H., Ammon, A., 2005. International outbreak of Salmonella Oranienburg due to German chocolate. BMC Infect. Dis. 5, 1-10. 